\title{
Effect of Application of Bio-Inoculants on Growth and Yield of Arachis hypogaea L. and Sesamum indicum $\mathrm{L}$.
}

\author{
Naresh Kumar", Anil Kumar, Ashok Shukla, Asha Ram, \\ Ram Bahadur and O.P. Chaturvedi
}

ICAR-Central Agroforestry Research Institute, Jhansi - 284 003, Uttar Pradesh, India

*Corresponding author

\section{A B S T R A C T}

\section{Keywords}

Arbuscular mycorrhizal fungi,

Azotobacter,

Oilseed crops,

Rhizobium and

phosphate

solubilizing bacteria

Article Info

Accepted:

20 December 2017

Available Online:

10 January 2018
The present study was carried out to assess the effect of bio-inoculants [arbuscular mycorrhizal fungi (AMF), rhizobium (Rhi)/azotobacter (Azo) and phosphate solubilizing bacteria (PSB)] on growth and yield of two important oilseed crops of Bundelkhand region, viz., Arachis hypogaea (groundnut) and Sesamum indicum (sesame). Study consisted of six treatments viz., AMF, Rhi/Azo, PSB, Rhi/Azo+PSB, AMF+Rhi/Azo+PSB and control. The recommended dose of DAP was applied in all the plots and treatments were imposed in respective plots. Each treatment was replicated five times in randomized block design. Results showed that most of the bio-inoculants significantly increased the observed parameters. In A. hypogaea, maximum plot yield was recorded in AMF+Rhi+PSB (260.8 g/plot) which was significantly higher than control. Similarly, significantly higher plot yield $(246.2 \mathrm{~g} / \mathrm{plot})$ was recorded in $S$. indicum with the application of AMF+Azo+PSB. Percent (\%) increase in plot yield over control in different treatments ranged from 3.2 to $25.3 \%$ in A. hypogaea and 31.1 to $53.6 \%$ in S. indicum. Combined application of bio-inoculants gave better results than single inoculation which suggested that bio-inoculants used under the study worked synergistically with each other. Hence, it may be concluded that combination of AMF+Rhi/Azo+PSB may be used to enhance the yield of A. hypogaea and S. indicum in Bundelkhand region of central India.

\section{Introduction}

India is a largest producer of oilseeds in the world and oilseed sector occupies an important position in the agricultural economy of the country (Rai et al., 2016). In terms of acreage, production and economic value, these crops are second only to food grains (Sharma, 2014). Major oilseed crops of India are groundnut (Arachis hypogaea L.), rapeseedmustard (Brassica napus L.), sesame
(Sesamum indicum L.), safflower (Carthamus tinctorius L.), niger (Guizotia abyssinica (Lf) Cass.), soybean (Glycine max (L.) Merr.), sunflower (Helianthus annuus L.), linseed (Linum usitatissimum L.) and castor (Ricinus communis L.) (Roy and Ahmad, 2015). Among these, A. hypogaea and S. indicum are most important oilseed crops of the Bundelkhand region of Central India (http://www.bundelkhandinfo.org.in/economy/ agriculture/major_minor.html). 
A. hypogaea is one of the world's most popular crops, cultivated in more than 100 countries. It accounts for around $25 \%$ of total oilseed production of our country. $S$. indicumis produced in about65 countries of the world and India is the largest producers of $S$. indicum. Our demand for vegetable oils and fats is increasing rapidly, but our production is still low.

In India, the average yield of most oilseed crops is extremely low as compared to other countries of the world. To increase their yield farmers use higher doses of chemical fertilizer which affect the soil and environment adversely. Adverse effects of chemical fertilizers, their high cost and the low purchasing power of small and marginal farmers have led to search for alternative strategies (Singh et al., 2011). One such approach could be the use of integrated nutrient management, which can save soil, environment and farmer's limited resources (Deaker et al., 2004; Reddy et al., 2016). Balanced and combined application of inorganic fertilizers along with bio-inoculants can increase the crop productivity (Adesemoye and Kloepper, 2009).

Enhanced crop yields due to use of bioinoculants viz., arbuscular mycorrhizal fungi (AMF), rhizobium, azotobacter and phosphate solubilizing bacteria (PSB) along with chemical fertilizers have been reported world over (Kumar et al., 2009; Zalate and Padmani, 2009; Babajide et al., 2014; Chavan et al., 2014; Reddy et al., 2016).

However, very limited work has been carried out on the subject under Central Indian conditions. Therefore, in present study, the effect of above-mentioned bio-inoculants when used along with inorganic fertilizer (diammonium phosphate, DAP) on growth and yield of $A$. hypogaea and $S$. indicum was investigated under field conditions.

\section{Materials and Methods}

\section{Site description}

The study was conducted at ICAR-Central Agroforestry Research Institute (CAFRI), Jhansi $\left(24^{\circ} 11^{\prime} \mathrm{N}\right.$ latitude and $78^{\circ} 17^{\prime} \mathrm{E}$ longitude), Uttar Pradesh, India. Mean annual rainfall of the region is $960 \mathrm{~mm}$, with an average of 52 rainy days per year. Mean maximum temperature ranges from $23.5{ }^{\circ} \mathrm{C}$ (January) to $47.4{ }^{\circ} \mathrm{C}$ (June) and mean minimum temperature from $4.1{ }^{\circ} \mathrm{C}$ (December) to $27.2{ }^{\circ} \mathrm{C}$ (June).

The main soil types at the experimental fields are red (alfisol) and black (vertisol). Soil $\mathrm{pH}$ varies from 5.70 to 6.78 and organic $\mathrm{C}$ from 0.38 to $0.67 \%$. The region has two distinct cropping seasons, viz., kharif (rainy season; July to October) and rabi (winter season; November to February). A. hypogaea and $S$. indicum are being grown during kharif season in Bundelkhand region.

\section{Biological materials}

The seeds of $A$. hypogaeaand S. indicumwere obtained from central seed store of ICARCAFRI, Jhansi. Arbuscular mycorrhizal fungi (AMF), rhizobium (Rhi)/azotobacter (Azo) and phosphate solubilizing bacteria (PSB) were used as bio-inoculants. Rhizobium (Rhi) was used in A. hypogaea, wheras azotobacter (Azo) was appliedin S. indicum. Consortium of two AMF species, namely Acaulospora scrobiculata Trappe and Rhizophagus irregularis (Blaszk., Wubet, Renker and Buscot) Walker and Schubler were used as inoculants. Their purified cultures are being maintained in sterilized sand on Zea mays L. under net-house conditions at the institute. Liquid cultures of rhizobium (for $A$. hypogaea), azotobacter and PSB were procured from CCS Agriculture University, Hissar, Haryana, India. 


\section{Application of bio-inoculants}

Ten times diluted AMF consortium (A. scrobiculata $+R$. irregularis) was applied 3-4 $\mathrm{cm}$ below seeds. For application of rhizobium or azotobacter or PSB, seeds were made sticky with the help of jaggery solution and applied @ $50 \mathrm{ml}$ liquid culture per $10 \mathrm{~kg}$ seed.

For combined inoculations of rhizobium or azotobacter and PSB, seeds were first coated with rhizobium or azotobacter, then after drying in shade, the coated seeds were inoculated with PSB.

\section{Experimental trials}

Separate field experiments on A. hypogaea and $S$. indicumwere conducted at experimental farm of the CAFRI, Jhansi during rainy season 2015 and 2016 , in $3 \mathrm{~m} \times 3 \mathrm{~m}$ size plots in a randomized block design with five replications. A total of six treatments viz., AMF, Rhi/Azo, PSB, Rhi/Azo+PSB, $\mathrm{AMF}+\mathrm{Rhi} / \mathrm{Azo}+\mathrm{PSB}$ and control (DAP alone) were imposed. All the cultural practices, recommended for the crops were followed. DAP was applied @ 60 and $40 \mathrm{~kg} \mathrm{P}_{2} \mathrm{O}_{5}$ per hectare for A. hypogaea and S. indicum, respectively before sowing in all experimental plots. To determine the effect of treatments on growth and yield, ten plants were chosen randomly from central part of each plot at maturity and observations on plant growth and yield were recorded. To exclude the border effect, remaining plants were harvested from central $2 \mathrm{~m} \times 2 \mathrm{~m}$ quadrate and observations on yield plot ${ }^{-1}$ were recorded.

\section{Statistical analysis}

Data were subjected to analysis of variance using the ANOVA procedure of the Web Agri Stat Package developed by ICAR Research Complex Goa, India. Statistical significance was determined at the $5 \%$ probability level.

\section{Results and Discussion}

Data on effect of bio-inoculants on growth and yield related parameters in A. hypogaea are presented in Table 1. Plant height was significantly increased by application of $\mathrm{AMF}+\mathrm{Rhi}+\mathrm{PSB}, \quad \mathrm{Rhi}+\mathrm{PSB}$ and AMF. $\mathrm{AMF}+\mathrm{Rhi}+\mathrm{PSB}$ and AMF significantly increased above ground biomass over control. All bio-inoculants significantly increased number of pods per plant. Its maximum value was recorded in $\mathrm{AMF}$ and $\mathrm{AMF}+\mathrm{Rhi}+\mathrm{PSB}$, while minimum was recorded in Rhi+PSB.

All bio-inoculants significantly increased plot yield over control. It was recorded maximum in AMF+Rhi+PSB (260.8 g), followed by AMF $(237.0 \mathrm{~g})$. Data on effect of bioinoculants on growth and yield of $S$. indicum are presented in Table 2. All bio-inoculants significantly increased plant height, number of capsules per plant, thousand seed weight and plot yield (Table 2). Dry shoot weight and number of seeds per capsule were increased by Azo+PSB, Azo and AMF+Azo+PSB. Differences among treatments in terms of dry root weight were non-significant. Maximum plot yield was recorded in AMF+Azo+PSB (246.2 g) which was at par with Azo, AMF, Azo+PSB and PSB.

The results showed that application of AMF, Rhi and PSB increased growth and yield in $A$. hypogaea under field conditions. Similar results were obtained in $S$. indicum after application with AMF+Azo+PSB. The per cent increase in plot yield in different treatments over control varied from 3.2 to $25.3 \%$ in A. hypogaea (Figure 1) and from 31.1 to $53.6 \%$ in $S$. indicum (Figure 2). Similar increase in yield after application of bio-inoculants has been reported by several workers in various crops (Toro et al., 1998; Zaidi et al., 2004; Zaidi and Khan, 2006; Meghvansi et al., 2008; Sarawgi et al., 2012; Shukla et al., 2016). 
Table.1 Effect of bio-inoculants on growth and yield of A. hypogaea

\begin{tabular}{|l|c|c|c|c|}
\hline Treatments* & $\begin{array}{c}\text { Plant height } \\
(\mathrm{cm})\end{array}$ & $\begin{array}{c}\text { Above ground dry biomass } \\
(\mathrm{g}) / \mathrm{plant}\end{array}$ & $\begin{array}{c}\text { Number of } \\
\text { pods/plant }\end{array}$ & $\begin{array}{c}\text { Plot yield } \\
(\mathrm{g})\end{array}$ \\
\hline AMIF & $38.7 \mathrm{ab}$ & $84.33 \mathrm{a}$ & $59 \mathrm{a}$ & $237.0 \mathrm{~b}$ \\
\hline Rhi & $34.4 \mathrm{bc}$ & $53.19 \mathrm{bc}$ & $44 \mathrm{~b}$ & $223.7 \mathrm{bc}$ \\
\hline PSB & $33.5 \mathrm{bc}$ & $65.06 \mathrm{~b}$ & $45 \mathrm{~b}$ & $231.8 \mathrm{~b}$ \\
\hline Rhi+PSB & $39.7 \mathrm{a}$ & $75.99 \mathrm{ab}$ & $41 \mathrm{~b}$ & $214.8 \mathrm{c}$ \\
\hline AMIF+Rhi+PSB & $39.3 \mathrm{a}$ & $87.32 \mathrm{a}$ & $58 \mathrm{a}$ & $260.8 \mathrm{a}$ \\
\hline Control & $29.8 \mathrm{c}$ & $47.43 \mathrm{bc}$ & $36 \mathrm{c}$ & $208.2 \mathrm{~d}$ \\
\hline
\end{tabular}

$* \mathrm{AMF}=$ arbuscular mycorrhizal fungi, $\mathrm{Rhi}=$ rhizobium, $\mathrm{PSB}=$ phosphate solubilizing bacteria

Table.2 Effect of bio-inoculants on growth and yield of S. indicum

\begin{tabular}{|l|l|l|l|l|l|l|l|}
\hline Treatments* & $\begin{array}{l}\text { Plant } \\
\text { height } \\
(\mathrm{cm})\end{array}$ & $\begin{array}{l}\text { Dry shoot } \\
\text { weight } \\
(\mathrm{g})\end{array}$ & $\begin{array}{l}\text { Dry root } \\
\text { weight } \\
(\mathrm{g})\end{array}$ & $\begin{array}{l}\text { Number of } \\
\text { capsules/ } \\
\text { plant }\end{array}$ & $\begin{array}{l}\text { Number of } \\
\text { seeds per } \\
\text { capsule }\end{array}$ & $\begin{array}{l}\text { Thousand } \\
\text { seed } \\
\text { weight }(\mathrm{g})\end{array}$ & $\begin{array}{l}\text { Plot } \\
\text { yield } \\
(\mathrm{g})\end{array}$ \\
\hline AMIF & $110.0 \mathrm{~b}$ & $8.46 \mathrm{~d}$ & $2.72 \mathrm{a}$ & $53.7 \mathrm{ab}$ & $20.9 \mathrm{~cd}$ & $3.25 \mathrm{a}$ & $222.6 \mathrm{a}$ \\
\hline Azo & $117.5 \mathrm{~b}$ & $10.47 \mathrm{~b}$ & $2.30 \mathrm{a}$ & $53.7 \mathrm{ab}$ & $28.0 \mathrm{ab}$ & $3.22 \mathrm{a}$ & $245.3 \mathrm{a}$ \\
\hline PSB & $108.4 \mathrm{~b}$ & $8.81 \mathrm{~cd}$ & $2.34 \mathrm{a}$ & $51.8 \mathrm{ab}$ & $19.0 \mathrm{~cd}$ & $3.10 \mathrm{bc}$ & $210.2 \mathrm{a}$ \\
\hline Az0+PSB & $111.8 \mathrm{~b}$ & $12.91 \mathrm{a}$ & $2.54 \mathrm{a}$ & $51.0 \mathrm{~b}$ & $32.8 \mathrm{a}$ & $3.17 \mathrm{ab}$ & $222.0 \mathrm{a}$ \\
\hline AMF+Az0+PSB & $113.0 \mathrm{ab}$ & $10.09 \mathrm{bc}$ & $2.42 \mathrm{a}$ & $55.2 \mathrm{a}$ & $23.8 \mathrm{bc}$ & $3.22 \mathrm{a}$ & $246.2 \mathrm{a}$ \\
\hline Control & $94.3 \mathrm{c}$ & $7.50 \mathrm{~d}$ & $2.25 \mathrm{a}$ & $45.1 \mathrm{c}$ & $17.6 \mathrm{~d}$ & $3.02 \mathrm{c}$ & $160.3 \mathrm{~b}$ \\
\hline
\end{tabular}

$* \mathrm{AMF}=$ arbuscular mycorrhizal fungi, $\mathrm{Rhi}=$ rhizobium, $\mathrm{PSB}=$ phosphate solubilizing bacteria

Fig.1 Per cent (\%) increase in plot yield by application of bio-inoculants over control in A. hypogaea

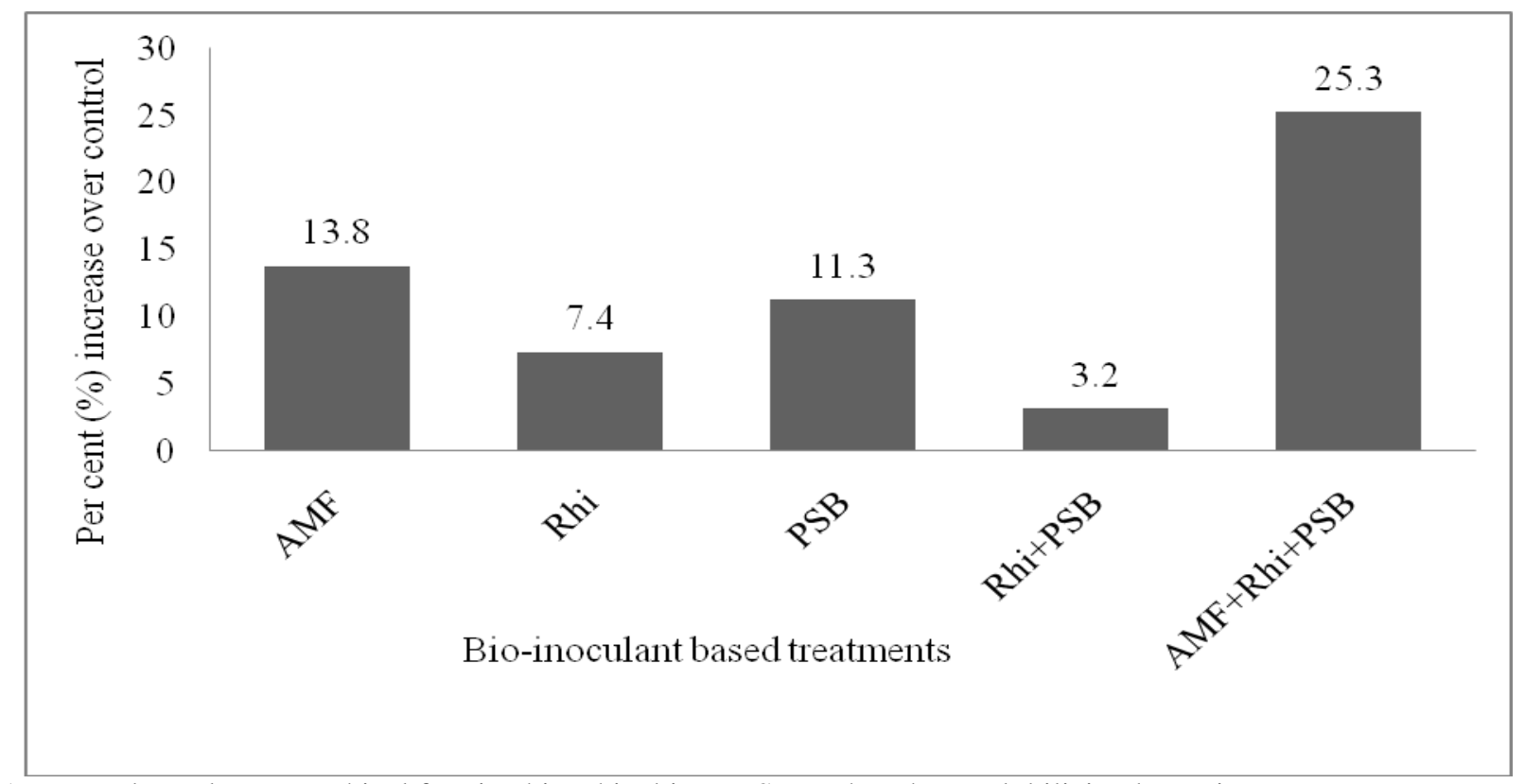

$\mathrm{AMF}=$ arbuscular mycorrhizal fungi, Rhi $=$ rhizobium, $\mathrm{PSB}=$ phosphate solubilizing bacteria 
Fig.2 Per cent (\%) increase in plot yield by application of bio-inoculants over control in S. indicum

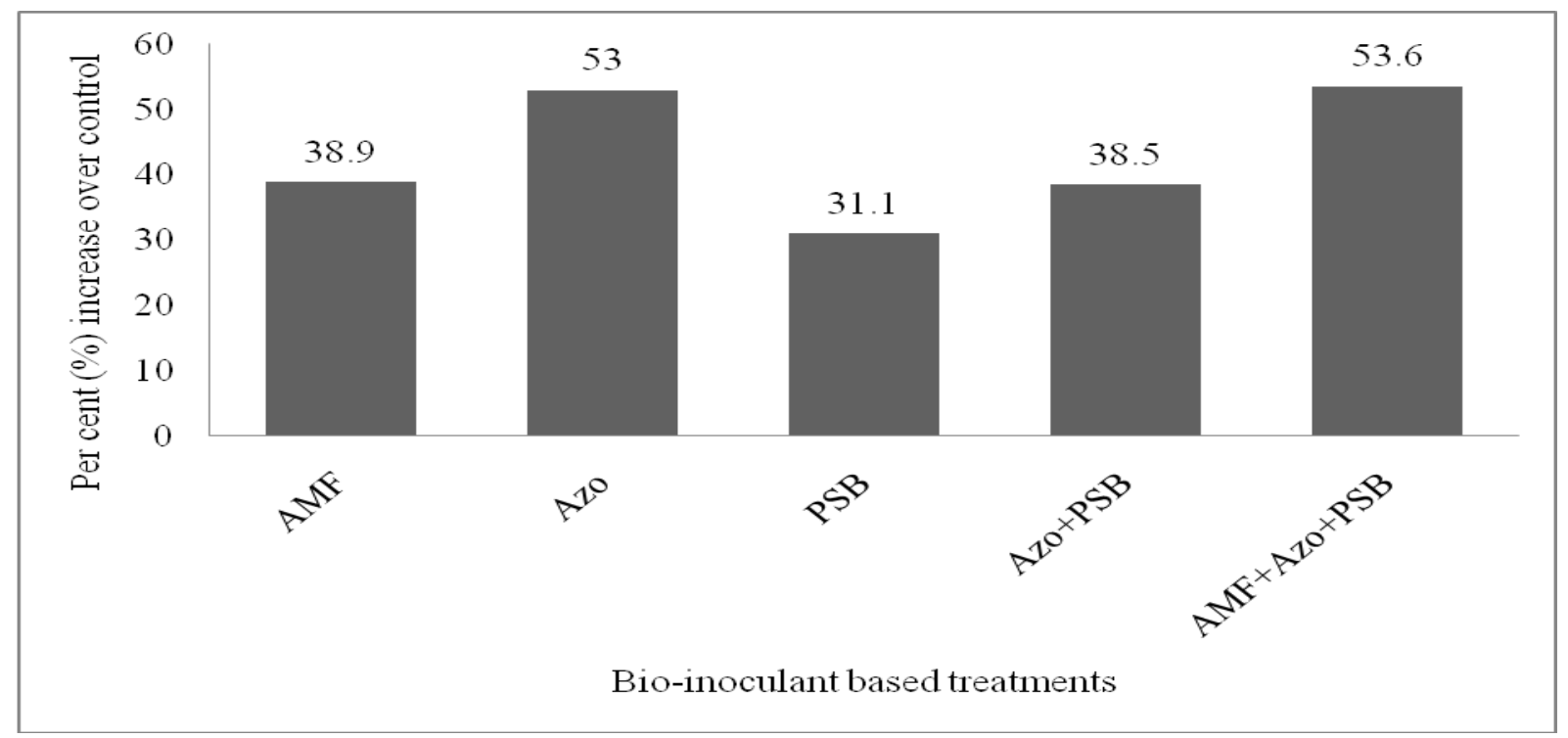

$\mathrm{AMF}=$ arbuscular mycorrhizal fungi, $\mathrm{Rhi}=$ rhizobium, $\mathrm{PSB}=$ phosphate solubilizing bacteria

Sabannavar and Lakshman (2008) investigated the effect of AMF (Glomus fasciculatum and Acaulospora laevis), PSB (Pseudomonas fluoresence) and Azotobacter chroococcum on growth and yield of two varieties (DS1 and E8) of S. indicum. They reported increased growth and yield with consortium of all three bio-inoculants over dual and single inoculation treatments. In another study, Sabannavar and Lakshman (2011) also reported more or less similar results with two different varieties (TSES1 and TSES4) of S. indicum. In A. hypogaea, higher growth and nutrient uptake in treatment inoculated with AMF and Bradyrhizobium along with ammonium nitrate and potassium phosphate was reported by Nambiar and Anjaiah (1989). El-Azouni et al., (2008) also reported the same associative effects of AMF with Bradyrhizobium on growth and nutrient uptake of $A$. hypogaea.

The results of present study revealed that combined inoculation with all the bioinoculants (AMF+Rhi/Azo+PSB) gave better results than single inoculations (AMF or
Rhi/Azo or PSB), with few exceptions. This showed that bio-inoculants used under study worked synergistically with each other. Similar results have been reported by different workers (Young et al., 1990; Barea et al., 2002; Meghvansi et al., 2008; Shukla et al., 2016). Hence, it was concluded that combined application of $\mathrm{AMF}+\mathrm{Rhi}+\mathrm{PSB}$ and $\mathrm{AMF}+\mathrm{Azo}+\mathrm{PSB}$ may be used to get improved yield of $A$. hypogaea and $S$. indicum, respectively in Bundelkhand region of central India.

\section{Acknowledgement}

The authors are thankful to the Director, ICAR-CAFRI, Jhansi, India for facilitating the research program. Ashok Shukla acknowledges funding (SB/FT/LS-366/2012) by Science and Engineering Research Board, New Delhi, India.

\section{Conflict of interest}

Authors declared that there is no conflict of interest. 


\section{References}

Adesemoye, A.O., and Kloepper, J.W., 2009. Plant-microbes interactions in enhanced fertilizer-use efficiency. Applied Microbiology and Biotechnology.85: 112.

Babajide, P.A., and Fagbola, O. 2014. Growth, yield and nutrient uptakes of sesame (Sesamum indicum linn.) as influenced by biofertilizer inoculants. International Journal of Current Microbiology and Applied Sciences. 3(8):859-879.

Barea, J.M., Toro, M., Orozco, M., Campos, E., and Azcon, R., 2002. The application of isotopic $\left({ }^{32} \mathrm{P}\right.$ and $\left.{ }^{15} \mathrm{~N}\right)$ dilution technique to evaluate the interactive effect of phosphatesolubilizing rhizobacteria, mycorrhizal fungi and Rhizobium to improve the agronomic efficiency of rock phosphate form legume crops. Nutrient Cycling and Agroecosystems. 63: 35-42.

Chavan, A.P., Jain, N.K., and Mahadkar, U.V. 2014. Direct and residual effects of fertilizers and biofertilizers on yield, nutrient uptake and economics of groundnut (Arachis hypogaea)-rice (Oryza sativa) cropping system. Indian Journal of Agronomy. 59(1):53-58.

Deaker, R., Roughley, R.J., and Kennedy, I.R. 2004. Legume seed inoculation technology - A review. Soil Biology and Biochemistry.36: 1275-1288.

El-Azouni, I.M., Hussein, Y., Shaaban. L.D. 2008. The associative effect of VA mycorrhizae with Bradyrhizobium as biofertilizers on growth and nutrient uptake of Arachis hypogaea. Research Journal of Agriculture and Biological Sciences. 4(2): 187-197.

Kumar, S., Pandey, P., and Maheshwari, D.K. 2009. Reduction in dose of chemical fertilizers and growth enhancement of sesame (Sesamum indicum L.) with application of rhizospheric competent Pseudomonas aeruginosa LES4. European Journal of Soil Biology. 45(4):334-340.

Meghvansi, M.K., Prasad, K., Harwani, D., and Mahna, S.K., 2008. Response of soybean cultivars toward inoculation with three arbuscular mycorrhizal fungi and Bradyrhizobium japonicum in the alluvial soil. European Journal of Soil Biology.44: 316-323.

Nambiar, P.T.C., and Anjaiah, V. 1989. Competition among strains of Brady rhizobium and vesicular-arbuscular mycorrhizae for groundnut (Arachis hypogaea L.) root infection and their effect on plant growth and yield. Biology and Fertility of Soils. 8(4):311-318.

Rai, S.K., Charak, D., and Bharat, R. 2016. Scenario of oilseed cropd across the globe. Plant Archives. 16(1):125-132.

Reddy, R.S, Triveni, S., and Chari, K.D. 2016. Biofertilizers for sustainable production in oil seed crops. Scholars Journal of Agriculture and Veterinary Sciences. 3(6):435-441.

Roy, R., and Ahmad, H. 2015. State agricultural profile of Uttar Pradesh (2014-2015). Agro-Economic Research Centre, University of Allahabad, Allahabad, Uttar Pradesh, India.

Sabannavar, S.J., and Lakshman, H.C. 2008. Interactions between Azotobacter, Pseudomonas and arbuscular mycorrhizal fungi on two varieties of Sesamum indicum L. Journal of Agronomy and Crop Science. 194(6): 470-478.

Sabannavar, S.J., and Lakshman, H.C. 2011. Synergistic interactions among Azotobacter, Pseudomonas, and arbuscular mycorrhizal fungi on two varieties of Sesamum Indicum L. Communications in Soil Science and Plant Analysis. 42(17): 2122-2133. 
Sarawgi, S.K., Chitale, S., Tiwarp, A., and Bhoj, S. 2012. Effect of phosphorus application along with PSB, Rhizobium and VAM on $\mathrm{P}$ fractionation and productivity of soybean (Glycine max). Indian Journal of Agronomy, 57: 55-60.

Sharma, V.P. 2014. Final report on problems and prospects of oilseeds production in India. Centre for Management in Agriculture, Indian Institute of Management, Ahmedabad, India.

Shukla, A., Kumar, A., Chaturvedi, O.P., Nagori, T., Kumar, N., and Gupta, A. 2016. Efficacy of rhizobial and phosphate-solubilizing bacteria and arbuscular mycorrhizal fungi to ameliorate shade response on six pulse crops. Agroforestry Systems (doi 10.1007/s10457-017-0070-0).

Singh, J.S., Pandey, V.C., and Singh, D.P. 2011. Efficient soil microorganisms: A new dimension for sustainable agriculture and environmental development. Agriculture, Ecosystems \&Environment. 140: 339-353.

Toro, M., Azcon, R., and Barea, J.M., 1998. The use of isotopic dilution techniques to evaluate the interactive effects of Rhizobium genotype, mycorrhizal fungi, phosphate solubilizing rhizobacteria and rock phosphate on nitrogen and phosphorus acquisition by Medicago sativa. New Phytologist. 138: 265-273.

Young, C.C., Chen, C.L., and Chao, C.C. 1990. Effect of Rhizobium, vesiculararbuscular mycorrhiza, and phosphate solubilizing bacteria on yield and mineral phosphorus uptake of crops in subtropical-tropical. Proceedings of the $14^{\text {th }}$ International Congress of Soil Science Transactions, Vol 3. International Society of Soil Science, Kyoto, pp. 55-60

Zaidi, A., and Khan, M.S. 2006. Coinoculation effects of phosphate solubilizing microorganisms and Glomus fasciculatum on green gramBradyrhizobium symbiosis. Turkish Journal of Agriculture and Forestry. 30: 223-230.

Zaidi, A., Khan, M.S., and Amil, M. 2004. Bioassociative effect of rhizospheric microorganisms on growth, yield, and nutrient uptake of greengram. Journal of Plant Nutrition. 27: 601-612.

Zalate, P.Y., and Padmani, D.R. 2009. Effect of organic manure and biofertilizers on yield, harvest index, shelling percentage and quality of kharif groundnut (Arachis hypogaea L.). International Journal of Agricultural Sciences. 5(2):417-419.

\section{How to cite this article:}

Naresh Kumar, Anil Kumar, Ashok Shukla, Asha Ram, Ram Bahadur and Chaturvedi, O.P. 2018. Effect of Application of Bio-Inoculants on Growth and Yield of Arachis hypogaea L. and Sesamum indicum L. Int.J.Curr.Microbiol.App.Sci. 7(01): 2869-2875. doi: https://doi.org/10.20546/ijcmas.2018.701.341 